\title{
Exploring Goal-Setting Strategies of Prospective Physical Education Teachers to Maintain Academic Performance
}

\author{
Jusuf Blegur 1, Aniq Hudiyah Bil Haq ${ }^{2}$, Muya Barida 3
}

DOI: $10.35445 /$ alishlah.v13i1. 539

\begin{tabular}{l}
\hline Article Info \\
\hline Keywords: \\
Prospective teachers of \\
physical education \\
Academic performance \\
Goal-setting strategies \\
Strategies for \\
maintaining academic \\
performance
\end{tabular}

Kata kunci:

Calon guru pendidikan jasmani

Kinerja akademik

Strategi penetapan

tujuan

Strategi untuk mempertahankan kinerja akademik

\begin{abstract}
Some students have successfully used goal-setting to maintain academic performance throughout their studies. Behind these successes, they implemented the strategy to the fullest, making their goals more manageable. This study explores the strategies of prospective physical education teachers using goal-setting to maintain academic performance. The research team used an exploratory qualitative approach to compare students' experiences with good and bad academic reputations in maintaining academic performance through observation, interview, and documentation techniques. There were 11 students involved, both those with good academic reputations and vice versa. Spradley's taxonomic analysis found that students had to reconstruct their way of learning because of traumatic experiences of academic failure and the economic limitations of the family. Goal-setting ensures that students complete their work on time and are more selective in using the clarity of information in lecturer learning designs. In addition, they reduce their learning challenges by learning and acting according to the assessment rubric, commit to each learning task and responsibility, use feedback to improve learning performance, and ensure all learning task needs by developing self-learning strategies.
\end{abstract}

\begin{abstract}
Abstrak
Beberapa mahasiswa telah berhasil menggunakan penetapan tujuan untuk mempertahankan kinerja akademis selama masa studinya. Dibalik kesuksesan tersebut, mereka menerapkan strategi secara maksimal, membuat pencapaian tujuan mereka lebih mudah dikelola. Penelitian ini bertujuan untuk mengeksplorasi strategi calon guru pendidikan jasmani menggunakan penetapan tujuan untuk menjaga kinerja akademik. Tim peneliti menggunakan pendekatan kualitatif eksploratif untuk membandingkan pengalaman mahasiswa yang memiliki reputasi akademik bagus dan buruk dalam menjaga performa akademik melalui teknik observasi, wawancara, dan dokumentasi. Ada 11 mahasiswa yang terlibat, baik yang memiliki reputasi akademik baik maupun sebaliknya. Analisis taksonomi Spradley menemukan bahwa mahasiswa harus merekonstruksi cara belajar mereka karena pengalaman traumatis dari kegagalan akademis dan keterbatasan ekonomi keluarga. Penetapan tujuan memastikan bahwa mahasiswa menyelesaikan pekerjaan mereka tepat waktu dan lebih selektif dalam menggunakan
\end{abstract}

\footnotetext{
${ }^{1}$ Universitas Kristen Artha Wacana, Kupang, Indonesia

Email: jusufblegur@ukaw.ac.id

${ }^{2}$ Universitas Muhammadiyah Kalimantan Timur, Samarinda, Indonesia

Email: ahbh@umkt.ac.id

3 Universitas Ahmad Dahlan, Yogyakarta, Indonesia

Email: muya.barida@bk.uad.ac.id
} 
kejelasan informasi dalam desain pembelajaran dosen. Selain itu, mereka mengurangi tantangan belajarnya dengan belajar dan bertindak sesuai dengan rubrik penilaian, berkomitmen pada setiap tugas dan tanggung jawab pembelajaran, menggunakan umpan balik untuk meningkatkan kinerja pembelajaran, dan memastikan semua kebutuhan tugas belajar dengan mengembangkan strategi pembelajaran mandiri.

\section{INTRODUCTION}

Students must be aware of the importance of "enjoying" the learning process and its dynamics, such as studying diligently, socializing flexibly, and neatly working on papers and presentations. Observations during the learning process found that learning awareness had a positive impact on students. For example, in the Microteaching course, they had satisfactory academic performance and results because students had high learning awareness. Students deserve satisfactory academic performance and results if they effectively manage goal-setting (Lawlor \& Hornyak, 2012; Yusuff, 2018). Academic performance is a tangible manifestation of students' readiness to be involved in learning activities, both short and long term. So if a student has adequate academic performance, he must have had many strategies that he got, both implicitly through the various analysis of lecturer assessment strategies and explicitly from the learning designs that the lecturer had set.

During learning activities, some students have good academic performance, and there is also the opposite. Indeed, it is motivated by various variables, both from within the student himself and from outside factors. For example goal-setting (Arsanti, 2009; Yusuff, 2018; Sides \& Cuevas, 2020) and lecturer or teacher feedback (Xhomara \& Bara, 2018; Wang \& Zhang, 2020). Indeed, not all students with good academic performance are stable and consistent; however, they have some strategies to overcome their learning difficulties. At different times, students who ignore the exploration process will still have problems with their academic performance. Academic performance is seen directly through specific work assignments, such as when they do paper presentations, classroom teaching exercises, or the results of their paperwork. Thus, an excellent academic performance is not an instant one but a "refinement" of a student's long exploration process.

Student learning performance can increase with the goal-setting (Locke \& Latham, 2002; Goerg, 2015). Their academic performance is satisfactory because it effectively manages goal-setting (Lawlor \& Hornyak, 2012; Yusuff, 2018). Goal-setting can stimulate students to use learning strategies independently and manage learning activities to increase academic success (Latham \& Locke, 1991; Yearta, Maitlis, \& Briner, 1995; Cheung, 2004; Abe, Ilogu, \& Madueke, 2014). Goalsetting can also be expressed as a strategy that students often use to transform learning activities (Cullen, Baranowski, \& Smith, 2001), commit to their learning goals (Lunenburg, 2011), and improve academic performance (Affandi \& Hastjarjo, 2011; Moeller, Theiler, \& Wu, 2012; Abe, Ilogu, \& Madueke, 2014).

Setting goals for academic performance has been tested successfully (VandeWalle, Cron, \& Slocum, 2001; Abe, Ilogu, \& Madueke, 2014; Neroni et al., 2018; Sides \& Cuevas, 2020). However, what technically regulates the tips for goal-setting success are listed in the research papers Dotson (2016) and James (2017). Dotson develops four steps: 1) Set goals specific, measurable, attainable, realistic, and time-sensitive; 2) Develop a plan of action; 3) Monitor progress frequently; 4) Celebrate successes-even the small ones. James then developed a goal-setting strategy using "The Youth Goal-Setting Map" into two sides, the beginning and the end. The beginning includes a purposeful category, identifying time-specific goals, and determining milestones. Otherwise, the ending consists of intermediate milestones, resources for reaching goals, barriers to achieving goals, and strategies for attaining goal achievement.

Students' success in improving academic performance needs to be explored. It becomes a new goal-setting strategy model for other students who have not been able to maintain and even improve their academic performance during the learning process to become more productive, collaborative, 
and complete. Dotson's goal-setting steps (2016) and James (2017) are still conceptual studies by viewing the previous manuscript. The purpose of this study focuses more on exploring the best practice of goal-setting strategies that students have undertaken to maintain and improve academic performance using Locke and Latham's Goal-Setting Theory.

\section{METHODS}

\section{Procedure}

The research establishes an exploratory and comparative qualitative research approach to students with a fair and stable academic performance with a low and unstable academic performance by referring to setting variables. This qualitative exploration and comparison shed light on what students do for their learning goals to get good or bad results, such as student learning goals or college student goals. This approach is considered more appropriate in answering the problem because researchers are more likely to explore the subject's experiences in depth through direct observation, in-depth interviews and documentation studies to find the meaning behind student academic performance (good or bad). Besides, expressions of more profound and meaningful feelings can only be reached through qualitative studies to form a "flow" of goal-setting for student academic performance.

\section{Research Subject}

The process begins with conducting interviews with 11 research subjects $(\mathrm{M}=25.4545 ; \mathrm{SD}=$ 1.50756); they are $8^{\text {th }}$-semester students of the Physical Education, Health, and Recreation Study Program Universitas Kristen Artha Wacana. Of the 11 subjects, six students $(\mathrm{M}=25.8333$; $\mathrm{SD}=$ 1.47196) interviewed were those with a history and reputation of high and stable academic performance, namely UR (24 years), LK (24 years), OL (26 years), KMMN (27 years), WHHSP (27 years), and MNM (27 years). Furthermore, the other five students ( $\mathrm{M}=25 ; \mathrm{SD}=1.58114$ ) are those who have a history and reputation for low academic performance, namely, EGM (24 years), ET (26 years), MT (27 years), MK (25 years), and MA (23 years). The interview process was carried out at various times and places according to the subjects' opportunity and agreement. It was carried out separately to avoid biased answers from each subject and provide a comfortable feeling in giving information. On several occasions, we conducted online interviews.

\section{Data Collection}

We used in-depth interviews while confirmed with observational data and documentation. In contrast to participatory observation (observing behaviour and social interactions), in-depth interviews focus on the subjects' strategies in setting goals and their reasons, how they control themselves in environmental responses, why they need assertiveness, and how they experience their examples. The questions concretized facts, views, and ideas that the subject plans, experiences, and applies during learning life. We develop questions using Edwin A. Locke and Gary P. Latham's goalsetting theory: clarity, challenge, commitment, feedback, and task complexity. Some examples of questions are "What are your goals for studying so far?" How do you achieve this goal? And what strategies do you use to maintain enthusiasm in realizing your dreams?. Furthermore, documentation techniques investigate subjects' interaction outside the campus and then confirm with research variables through in-depth interviews and participatory observations.

\section{Data Analysis}

The analysis process used Spradley's (1979) taxonomic model to explore the meaning of student learning behavior to maintain and improve their academic performance and achievement. The domains focused on exploring goal-setting are causation, rationale, and the way to the goal. Simultaneously, the analytical procedure we adopted from Miles \& Huberman (1994) includes data reduction, data presentation, and verification/conclusion. 


\section{FINDINGS AND DISCUSSION}

\section{Clarity}

Several students looked so "relaxed" during their performance in the class. They do not encounter significant difficulties. It does not indicate that learning is done "lightly", but they already have a goal for a learning program package for one semester. Students realize that they must acquire some knowledge and skills and develop as their learning goals during college. It certainly stimulates them to study hard and independently (Cheung, 2004) to achieve academic success (Moeller, Theiler, \& Wu, 2012; Abe, Ilogu, \& Madueke, 2014; Dotson, 2016). Although there are also students who commit some deviations in some instances, they are forced to perform less well for specific reasons, but they can accumulate maximum performance. Educators stimulate this difference. For example, the case experienced by a student when he does not work optimally on an assignment depends on the educator's performance who takes the course. When students have goals, the consistency of educators in performing in class also contributes to achieving the goals that students have set.

Another problem that also contributes to setting student goals is past college experiences and economic limitations. The evidence of their failure in previous studies suggests that they must be more selective in using their college time. Just imagine, they have spent quite a long time for 3 to 6 semesters, but it turns out that they have to end because of their negligence. Of course, during that time, students must have the courage to take attitudes and decisions to change, and they start by setting goals for those changes. At a minimum, they aim to complete the study for four years ( 8 semesters) so that during semester learning, they must complete each course, assignment and responsibility at each learning meeting. The case mentioned shows that students' goal-setting helps them think more clearly and improve their emotions (Monzani, Ripoll, \& Peiró, 2015). It also allows students to develop their study plans for their academic performance and perceive their learning experiences to be even better (Yusuff, 2018).

Economic problems also contribute to students' ambitions in completing their studies immediately. Indeed, when examined, they come from families that are "economically limited", because, at the same time, they are funded for college. However, their parents or guardians also have other responsibilities to send their younger siblings to school, and so forth. Of course, with these conditions, family money is used effectively to be efficient. If he fails for just one course, additional funding must be spent to reprogram/retest the course next semester. So the goal of students is to finish school on time to be independent, and work immediately to make money while helping the family economy. The stimulants that most motivated them to finish college on time were failure experiences in the previous school and family economic problems. These two reasons make students focus, strive, be persistent, and develop various strategies to succeed in multiple academic tasks (Lunenburg, 2011; Bakar et al., 2014).

\section{Challenge}

Students who already have goals also have several ways to achieve them. They carry out various strategies to transform during their learning activities (Cullen, Baranowski, \& Smith, 2001). They become more optimistic, diligent, and consistent with doing and even completing many jobs on time. They set aside more time and initiate learning performance simulations from lecturers whose assessments are "strict". They feel that the rigorous assessment process is not a way for them to become afraid of learning but rather guides them in looking for ways to succeed. Students do exciting ways to make it happen to achieve their goals (perform well). For example, the first trace the Semester Lesson Plan from the lecturers. Professional lecturers have a learning plan that includes several materials, assignments, indicators, and an assessment rubric. Cheng, Richardson, \& Newby (2020) introduce this learning information storefront as a digital badge. These digital badges can help students promote strategic management, encourage persistence and dedicated behaviour for 
learning tasks, and improve learning performance. It is a challenge and also an opportunity for students to prepare themselves before the meeting takes place.

By exploring various materials, indicators, and assessment rubrics in lectures, students will find it easier to take strategic actions to suit the lecturer's plans and sets' performance requirements. These actions include opening materials through journals, reading books, reading proceedings, both online and offline. They can do this quickly because the lecturers have also given them instructions in accessing these sites, for example, through the Science and Technology Index link, Directory Open Access Journal, and Google Scholar. They usually use easier links because of language limitations. This strategic action is only done for cognitive tasks or materials. They prepare performance tasks, such as oral presentations and teaching practice, with intense preparations at their boarding house or house. They can do it independently or even with colleagues' help because all assessment rubrics (including) the oral performance rubric are listed in the lecturer's Semester Learning Plan.

Their efforts to achieve success also do not necessarily make them move away from various social relations. Although the research of Blegur et al. (2017) has proven that social relations can also lead to student disciplinary behaviour, but in the case of this study, students were able to maintain the proportion of their social relations carefully. When assignments have to be submitted, they must know which peers can provide guidance, assistance, and even support them to succeed. For example, in Microteaching lectures, students are in study groups, so they need friends who can provide an objective assessment according to the instrument and assessment rubric. This objectivity can help students make improvements to the quality of their performance (Micro teaching). So these social relations students also use it to achieve the goals they have set. Some students whose performance has not been maximized neglect to make early preparations because they live in "unhealthy" social relationships, especially when they are in "boarding houses". Then the setting of study goals will be very beneficial for the success of their academic performance. As a result, it was concluded that rigorous assessment and peer influence were forms of students' challenges. This challenge can be faced if students have the right goal-setting because goal-setting leads to change in the development of task performance from time to time (Asmus et al., 2015).

\section{Commitment}

Every student aims to make his graduation on time, have good knowledge, attitudes, and skills, and be useful to the family, society, and the country. This goal needs to be realized with various strategic actions from students. They can start by coordinating and communicating with the lecturers. Communication and coordination generally relate to writing papers, composing essays, making presentations, and others. This communication is the primary evidence that students are committed to completing specific courses because student commitment has successfully moderated their learning performance (Seitjs \& Latham, 2011) and realized developing their competence by mastering challenging situations (Lunenburg, 2011). Many students neglect communication and coordination. As a result, they deviated slightly from the lecturer's assignment, even though the project was listed along with the time they were collected on the Semester Lesson Plan sheet. Coordination and communication ensure that tasks and materials are carried out according to instructions, such as paper templates, strategies for introducing, discussing, and writing quotations and composing correct references according to the American Psychological Association's style.

In this case, students can experience stress because they do not submit assignments on time. This condition can make it difficult for them to perform optimally because their enthusiasm for learning can decrease. Therefore, they work around this by completing assignments on time and getting objective feedback on their work. The objectivity of lecturers or colleagues in providing grades is a way for students to improve their learning performance. They need a little concentration on variables that are not yet optimal, for example, how to discuss the results of a paper, strategies for using social cues in presentations, and strategies for using feedback in teaching practices. If their negligence is detected carefully, it is easy for them to improve, and their enthusiasm is well 
maintained. It will be different in learning activities that focus on "justification" because this will make students dissolve in various feelings of disappointment because they have to endure things they do not know.

Correcting mistakes is a student manifestation of a sense of belonging to the quality of their learning. They are committed to improving themselves in various learning tasks. People can commit to various things, including agreements, forming networks or collaborations, and so on (Blegur, 2020). It is an effort to maintain enthusiasm and realize student goals in learning. Some students often become disappointed because their expectations do not match reality. They can neglect their duties and responsibilities in learning, which will be a big problem for their performance development. Several learning cases have "forced" students to continue working through their various performances, so those who ignore their duties and responsibilities will experience problems. However, students who have goals are more focused on tasks and responsibilities as a form of self-existence to achieve their goals. So the goals that students set can give them the enthusiasm to explore themselves.

\section{Feedback}

It is not common knowledge that families, especially mothers, fathers, and brothers and sisters, are often loyal supporters of someone. This support is more in the form of support for the duration of the lecture. They support studying on time so they can graduate immediately and look for work or even create jobs. Every student has a different economic background, so it is natural for parents to ask, "what semester is it already in", "when is graduation?" They want their children to get a steady income to help the family economy immediately, or they do not become "dependents" of the family in terms of financing. This family support directly makes students feel "burdened" because it is responsible for completing lectures. Moreover, they also experience how heavy the family must bear the funding to educate students and their younger siblings. When getting phone calls or visits from parents, of course, the question their study progress. This question becomes encouraging feedback and reminds students of their educational goals. Through feedback or improvement in student performance to be better while reducing the negative impact of anxiety (Núñez-Peña, Bono, \& Pellicioni, 2015), and confirming academic performance (Denton, 2014; Torres \& Anguiano, 2016). As a result, lecturers also need to support students in realizing their goals by improving academic performance.

Students bring their work with various limitations; they need suggestions and solutions from the lecturers. When they are in a supportive learning climate, advice helps them maintain emotional stability while increasing their chances of performing at their best. Morisano's (2013) and Wang \& Zhang's (2020) research results have provided evidence that feedback affects student academic performance, where feedback promotes student engagement, overcomes obstacles, and high assessment diversity. Thus, even with various challenging tasks, they can complete them when they get positive feedback, support, and solutions. Some students experience disappointment because of the lack of time available from the lecturers to provide services and even ignore suggestions and solutions. The disappointment is none other than that they need confirmation and the lecturers' objectivity in evaluating the results of their work. At the same time, they do not get it. Goal-setting focuses more on substantive matters such as improving performance, hence facilitating lecturers in facilitating suggestions and solutions. As a result, feedback is a medium for improving student academic performance (Xhomara \& Bara, 2018) and as evidence of the professionalism of lecturers when teaching (Mamoon-Al-Bashi, Kabir, \& Rahman, 2016).

The participation of peers in the study class and outside the study class also helps maintain and ensure students' enthusiasm to achieve their goals. It is motivated by the learning process involving more study and work in groups. For example, in the Learning Evaluation course, students are formed by 3-5 people per study group and Microteaching courses and involve students in teaching practice groups. The role of colleagues in supporting enthusiasm is to be able to carry out supportive, objective cooperation in providing peer assessments and to be able to complete 
responsibilities according to shared commitments. On the other hand, communication space, which is not limited to study classes, allows students to access information and communicate any problems with colleagues and lecturers through the WhatsApp group. If we look at this phenomenon, the dominant basis in encouraging student enthusiasm to achieve goals is an openness to access information, speed of responding, and instruments to achieve assessment standards for courses.

\section{Task Complexity}

Every student has a way to achieve their goals, for example doing every assignment the lecturer gives, collecting on time, or doing maximum practise/performance. Several courses have equipped students with many rubrics and assignment indicators and assessments listed in the Semester Learning Plan to increase students' chances of succeeding. However, there are still students who have not been able to maximize these opportunities. Students' goal in a limited time is completing assignments, performing well, and getting high completeness scores. So they will achieve everything if they succeed in meeting the assessment indicators from the lecturers. They only need to achieve their goals by observing each task and responsibility. Of course, with the setting of goals, motivation to learn will be better (Dony \& Rahmat, 2013; Lutfianawati, Nugraha, \& Rachmahana, 2014). Indeed, some cases are quite challenging, such as compiling a paper (in a quotation style or compiling references, or doing teaching practice in front of the class). It is a severe problem for those with low self-esteem and self-confidence.

The two things above are very troublesome for some students because they are so "unfamiliar" with writing activities and performance-based learning activities. For this reason, some of them are not surprised to experience failure, whereas, for those who do, they perform simulated actions at home (for performance practice) and watch videos on youtube for citing and reference composing techniques. For students on "bona fide" campuses, maybe this is a common thing, but for us, this is a serious problem among students. Each rubric and assessment indicator has been listed in the learning planning document so that the severe problem students face is controlling their psychosocial aspects. Thus, students who can control their psychosocial, then they can quickly achieve their goals. It motivates the lecturer to prepare learning based on learning outcomes related to cognitive processes, internalization of attitudes, and actualization of skills during learning. Some people can "enjoy it" and end up achieving reasonable goals; even some have graduated from undergraduate school ahead of others.

The achievement of goals is easier because the lecturers have prepared several "keywords" (designing rubrics and assessment indicators) to focus on exploration, creativity in finding sources of information, and critical in deciding achievement strategies. Simultaneously, they also have a more effective time and are more selective in determining strategic actions in achieving goals. Students who find it difficult to ignore their goals, ignoring "keywords" during the lecture process. They find it difficult to determine priorities, especially when they never understand the direction and goals during the semester's lecture, even though rubrics and indicators decide each assessment decision. For this reason, each lecturer needs to prepare rubrics and assessment indicators to increase the chances of students determining priorities and having a work pattern that suits their goals.

\section{Goal-Setting: New Strategies Leads to Academic Success}

By reviewing the five domain strategies above, the synthesis is that the goal-setting for each individual has different dynamics. It is based on each individual's perspective on interpreting failure or success (Acevedo-gil \& Zerquera, 2016). Previous experiences of others can influence goalsetting. Goal-setting is closely related to the environmental function that controls goals under individual expectations from society. For students, goal-setting is influenced by lecturers, parents, peers, and economic factors, but the right goal-setting is following the individual's circumstances (Tosi, Locke, \& Latham, 1991; Latham, 2016;). Sometimes in setting individual goals, a person will consider what things are acceptable to the community or surroundings. Almost all students have the 
main goal to graduate on time with a good GPA. However, detailed goal-setting will create systematic and measured strategies to solve many challenges, even assuming that the difficulties faced are solely a form of being a challenge towards the goal.

Some of the students have more detailed goals during their lectures. For example, some say they want to graduate on time with perfect scores or want to graduate on time while carrying out activities outside of lectures. It can be said that the student's goal-setting is more challenging. Accuracy in adjusting goals and the size of the challenges faced by a person affects their performance in achieving goals. It varies for each individual so that there are students who have good grades, and there are students who have bad grades (Latham \& Locke, 1991). The more the goal-setting described by a person, the more straightforward and more prominent the strategy that leads someone to aim at his goals. So goal-setting is also influenced by cognitive factors and the individual. It is clear that this goal-setting also affects self-regulation in a person to achieve maximum performance (Arsanti, 2009; Tubbs \& Ekeberg, 2011; Latham, 2016).

Thus, goal-setting can be concluded as a continuous process and is not only done at the beginning by expressing someone's wishes. Clear commitment pieces of evidence focus on the process and not on results so that the individual can describe his goals. Well, it will go hand in hand with his actions directing that goal. A person's success in forming one goal in one area will make it easier to form one goal in different areas, meaning that someone who succeeds in achieving his goal in one area will lead him to succeed in other areas (Bakar et al., 2014). Good goal-setting will make it easier for someone to measure their achievement because, in the beginning, they already have their standard of success. In this study, we found that the faculty factor in describing an exact form of assessment would make it easier for students to know their position (Bakar et al., 2014). Someone who has the right goal-setting will have a good impact because goals are positively related to exam performance (Cao \& Nietfeld, 2007). Environmental factors help a person in making his goals specific and clear. The forms given by the environment include orientation regarding the goals desired by a person and effective and efficient achievement strategies (Morisano, 2013; Bakar et al., 2014).

The strategy for student goals-setting to maintain academic performance is synthesized into three significant parts-first, pre. Students review various obstacles and even failures in their past academics and design what steps or actions they will take to become academically successful. This section is very "challenging" because students who have failed will be more selective in determining learning actions to succeed. This pre-section includes: a) Taking responsibility for the family economy so that its presence does not burden the family in terms of funding, b) Reviewing academic performance and previous learning outcomes so that they can choose a campus, major, and those learning strategies are more appropriate for academic success, and, c) Determining the main priority of students, namely graduating/ graduation on time, to find immediately and even create jobs.

Second, action. After reviewing past academic experiences, students must take concrete and practical actions for successful academic performance. The students do three crucial things, including a) Students begin to explore forms of assignments and assessment techniques (cognitive, affective, and psychomotor) so that it follows the "preferences" of the lecturer in assessing the academic performance and learning outcomes of students. It is because each lecturer has indicators and an assessment rubric in the Semester Learning Plan, b) After finding the "meaning" of the assessment strategy from the lecturer, students must complete the assignment on time, and that they can do it before the assignment is given through simulations at the boarding house or home. To meet the assessment indicators, students can work with colleagues or family members to carry out exercises or simulations on assignments, c) If the indicators and rubrics have been distributed by the lecturer in the Semester Learning Plan, students can easily evaluate the results of their performance to assess their level of achievement or success.

Lastly is the part, post. Students evaluate the actions that have been taken. This evaluation can be done through the results of lecturer assessment performance, both formative and summative. 
This post-reflection includes a) Students check the results of lecturer assessments that are not limited to accumulative scores, such as 70,80 , or A, B, C, and others but are more detailed in indicators and lecturer assessment rubrics. This method is more practical to help students find negligence or shortcomings that they have not fulfilled as a standard of academic performance, $b$ ) Students confirm with the lecturer regarding their lack of academic performance to get information or clarification and are credible. In addition, through this method, students have the potential to improve their grades for meetings or to learn performance at the next meeting or the final meeting, c) There are actions that students lead; namely they revise and or eliminate ineffective learning methods in supporting their academic performance while maintaining methods and learning actions that support academic performance. It is a manifestation of feedback on the results of action and a commitment to succeed at the end of semester learning.

\section{Goal-setting strategy}

Pre

Responsible for the

family economy

Review academic

performance and

previous study results

Graduation on time

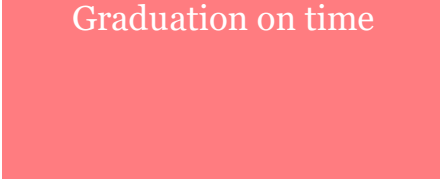

Action

Examining lecturer

assessment strategies in

Semester Learning Plans

Complete tasks on time

and according to

indicators

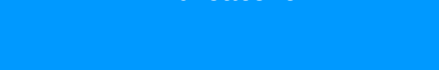

Examining the level of

success through

indicators and lecturer

assessment rubrics
Reviewing the level of success through

semester performance

Consulting with

lecturers to "improve"

performance

Maintaining productive

actions and revise

unproductive actions

\section{Figure 1. Students' goal-setting strategy in maintaining academic performance}

\section{CONCLUSION}

Goal-setting has helped students focus, streamline time, streamline energy, and be more enthusiastic about exploring. This objective also helps select the various requirements and recommendations that the lecturer conveys through learning activities, for example, various indicators and research rubrics listed in the Semester Learning Plan. This goal-setting is evidence that students have priority in their lecturing and learning activities. Every learning activity they carry out must be relevant to the goals they have set. Lecturers in the learning class through assignments, tests, and exams do not complain about difficulty but encourage them to seek more information and experience to complete assignments from the lecturers. They also simulate rubrics and indicators for lecturer assessments down to the smallest units to maximize their learning performance in the classroom.

Students have a general goal of completing studies in the shortest time, so they must ensure that they pass all courses with satisfactory results. Their consistency and commitment to each lecturer's instruction are an integral part of achieving their goals. Another thing that contributes to achieving student goals more "real" is the rubric and assessment indicators that have been clearly stated in the Semester Learning Plan. A clear assessment from the lecturer becomes a kind of "answer key" for students to immediately prepare for assignments so that they are not late in collecting, 
ignoring any instructions, and are predictive and anticipatory of the grades they get at the end of the semester. Thus, students' goal-setting strategy in completing their lectures becomes lighter because they have facilitated their rubrics and assessment indicators.

\section{ACKNOWLEDGEMENT}

The research team would like to thank the Directorate of Research and Community Service, Ministry of Education and Culture, for sponsoring research activities on the Basic Research Scheme through contract number: 1064/LL8/PG/KM/2020.

\section{REFERENCES}

Abe, I. I., Ilogu, G. C., \& Madueke, I. L. (2014). Effects of Goal-Setting Skills on Students' Academic Performance in English Language in Enugu Nigeria. New Approach in Educational Research, 3(2), 93-99. https://doi.org/10.7821/naer.3.2.93-99

Acevedo-Gil, N., \& Zerquera, D. D. (2016). Community College First-Year Experience Programs: Examining Student Access, Experience, and Success from the Student Perspective. New Directions for Community Colleges, 175, 71-82. https://doi.org/10.1002/cc.20213

Affandi, G. S., \& Hastjarjo, T. D. (2011). Pengaruh Tipe Penentuan Tujuan (Goal Setting) terhadap Performansi Bahasa Inggris Siswa: Dengan Efikasi Diri dan Kemampuan Awal Bahasa Inggris sebagai Kovariabel. Jurnal Psikologi Tabularasa, 6(1), 277-288. Retrieved from http://jurnal.unmer.ac.id/index.php/jpt/article/view/181

Arsanti, T. A. (2009). Hubungan antara Penetapan Tujuan, Self-Efficacy dan Kinerja. Jurnal Bisnis dan Ekonomi, 16(2), 97-110. https://www.unisbank.ac.id/ojs/index.php/fe3/article/view/318

Asmus, S., Karl, F., Monhen, A., \& Reinhart, G. (2015). The Impact of Goal-Setting on Worker Performance-Empirical Evidence from a Real-Effort Production Experiment. Procedia CIRP, 26, 127-132. https://doi.org/10.1016/j.procir.2015.02.086

Bakar, Z. A., Yun, L. M., Keow, N. S., \& Li, T. H. (2014). Goal-Setting Learning Principles: A Lesson from Practitioner. Journal of Educational and Learning, 8(1), 41-50. http://dx.doi.org/10.11591/edulearn.v8i1.204

Blegur, J. (2020). Soft Skills untuk Prestasi Belajar: Disiplin, Percaya Diri, Konsep Diri Akademik, Penetapan Tujuan, Tanggung Jawab, Komitmen, Kontrol Diri. Surabaya: Scopindo Media Pustaka.

Blegur, J., Wasak, M. R. P., Tlonaen, Z. A., \& Manggoa, M. A. (2017). Students' Behaviour of Indiscipline Syndrome in Teaching and Learning Process. Educational Administration Research and Review, 1(2), 37-41. Retrieved from http://ejournal.upi.edu/index.php/EAR/article/view/7467

Cao, L., \& Nietfeld, J. L (2007). Examining Relationships between Achievement Goals, Study Strategies, and Class Performance in Educational Psychology. Teaching Educational Psychology, 2(1), 1-20.

Cheng, Z., Richardson, J. C., \& Newby, T. J. (2020). Using Digital Badges as Goal-Setting Facilitators: A Multiple Case Study. $J$ Comput High Educ, 32, 406-428. https://doi.org/10.1007/s12528-019-09240-Z

Cheung, E. (2014). Goal Setting as Motivational Tool in Student's Self-Regulated Learning. Educational Research Quarterly, 27(3), 3-9.

Cullen, K. W., Baranowski, T., \& Smith, S. P. (2001). Using Goal Setting as a Strategy for Dietary Behavior Change. Journal of the American Dietetic Association, 101(5), 562-566. https://doi.org/10.1016/Soo02-8223(01)00140-7

Denton, D. W. (2014) Using Screen Capture Feedback to Improve Academic Performance. Tech Trends: Linking Research and Practice to Improve Learning, 58(6), 51-56. https://doi.org/10.1007/s11528-014-0803-0

Dony, H. A., \& Rahmat, D. W. (2013). Strategi Goal Setting untuk Meningkatkan Motivasi Belajar Mahasiswa PTM Unnes Mata Kuliah Kinematika dan Dinamika. Jurnal Penelitian Pendidikan, 30(1), 17-22. DOI: 10.15294/jpp.v30i1.5662

Dotson, S. R. (2016). Goal Setting to Increase Student Academic Performance. Journal of School Administration Research and Development, 1(1), 44-46. https://doi.org/10.32674/jsard.v1i1.1908 
Goerg, S. J. (2015). Goal Setting and Worker Motivation: Individual Work Goals can Increase a Worker's Performance, but they Need to be Chosen Wisely. IZA Word of Labor, 178, 1-10. Retrieved from https://wol.iza.org/articles/goal-setting-and-worker-motivation

James, A. G. (2017). A Theoretically Based, Easy-to-use Tool for Promoting Goal-Setting Behaviors in Youths. Journal of Extension, 55(1), 1-9.

Latham, G. P. (2016). Goal Setting: A Possible Theoretical Framework for Examining the Effect of Priming Goals on Organizational Behavior. Current Opinion in Psychology, 12, 85-88. https://doi.org/10.1016/j.copsyc.2016.07.005

Latham, G. P., \& Locke, E. A. (1991). Self-Regulation through Goal Setting. Organizational Behavior and Human Decision Processes, 5o, 212-247. https://doi.org/10.1016/07495978(91)90021-K

Lawlor, K. B., \& Hornyak, M. J. (2012). Smart Goals: How the Application of Smart Goals can Contribute to Achievement of Student Learning Outcomes. Developments in Business Simulation and Experiential Learning, 39, 259-267. Retrieved from https://journals.tdl.org/absel/index.php/absel/article/view/90

Locke E. A., \& Latham, G. P. (1990). A Theory of Goal Setting and Task Performance. Englewood Cliffs, NJ: Prentice Hall.

Locke, E. A., \& Latham, G. P. (2002). Building a Practically useful Theory of Goal Setting and Task Motivation: A 35-Year Odyssey. American Psychologist, 57(9), 705-717. https://doi.org/10.1037/0003-066X.57.9.705

Locke, E. A., \& Latham, G. P. (2006). New Directions in Goal-Setting Theory. Association for Psychological Science, 15(5), 265-268. https://doi.org/10.1111/j.1467-8721.2006.00449.X

Lunenburg, F. C. (2011). Goal-Setting Theory of Motivation. International Journal of Management, Business, and Administration, 15(1), 1-6.

Lutfiana, D., Nugraha, R. S. P., \& Rachmahana, R. S. (2014). Pengaruh Pelatihan Goal Setting terhadap Motivasi Belajar Bahasa Inggris Siswa. Jurnal Intervensi Psikologi, 5(2), 125-138. DOI: https://doi.org/10.20885/intervensipsikologi.vol5.iss2.art8

Mamoon-Al-Bashir, Kabir, R., \& Rahman, I. (2016). The Value and Effectiveness of Feedback in Improving Students' Learning and Professionalizing Teaching in Higher Education. Journal of Education Practice, 7(16), 38-41.

Miles, M. B., \& Huberman, A. M. (1994). Qualitative Data Analysis: An Expanded Sourcebook. London: Sage Publications.

Moeller, A. J., Theiler, J. M., \& Wu, C. (2012). Goal Setting and Student Achievement: A Longitudinal Study. The Modern Language Journal, 96(2), 153-169. https://doi.org/10.1111/j.15404781.2011.01231.X

Monzani, L., Ripoll, P., \& Peiró, J. M. (2015). Winning the Hearts and Minds of Followers: The Interactive Effects of Followers' Emotional Competencies and Goal Setting Types on Trust in Leadership. Revista Latinoamericana de Psicologia, 47(1), 1-15. https://doi.org/10.1016/S0120-0534(15)30001-7

Morisano, D. (2013). Goal Setting in the Academic Arena. In E. A. Locke \& G. P. Latham (Eds.), New Developments in Goal Setting and Task Performance (p. 495-506). New York: Routledge.

Neroni, J., Meijs, C., Leontjevas, R., Kirschner, P. A., \& de Groot, R. H. M. (2018). Goal Orientation and Academic Performance in Adult Distance Education. International Review of Research in Open and Distributed Learning, 19(2), 192-208. https://doi.org/10.19173/irrodl.v19i2.3440

Núñez-Peña, M. I., Bono, R., \& Pellicioni, M. S. (2015). Feedback on Students' Performance: A Possible Way of Reducing the Negative Effect of Math Anxiety in Higher Education. International Journal of Educational Research, 70, 80-87. DOI: 10.1016/j.ijer.2015.02.005

Seitjs, G., \& Latham, G. P. (2011). The Effect of Commitment to a Learning Goal, Self-Efficacy, and the Interaction between Learning Goal Difficulty and Commitment on Performance in a Business Simulation. Human Performance, 23(3), 189-204. DOI: 10.1080/08959285.2011.580807

Sides, J. D., \& Cuevas, J. A. (2020). Effect of Goal Setting for Motivation, Self-Efficacy, and Performance in Elementary Mathematics. International Journal of Instruction, 13(4), 1-16. https://doi.org/10.29333/iji.2020.1341a

Spardley, P. J. (1979). The Ethnographic Interview. New York: Holt, Renihart and Winston.

Torres, J. T., \& Anguiano, C. J. (2016). Interpreting Feedback: A Discourse Analysis of Teacher 
Feedback and Student Identity. Practitioner Research in Higher Education, 1O(2), 2-11.

Tosi, H. L., Locke, E. A., \& Latham, G. P. (1991). A Theory of Goal Setting and Task Performance. The Academy of Management Review, 16(2), 480. https://doi.org/10.5465/amr.1991.4278976

Tubbs, M. E., \& Ekeberg, S. E. (2011). The Role of Intentions in Work Implications for Motivation: Theory Goal-Setting. The Academy of Management Review, 16(1), 180-199.

VandeWalle, D., Cron, W. L., \& Slocum, J. W., Jr. (2001). The Role of Goal Orientation Following Performance Feedback. Journal of Applied Psychology, 86(4), 629-640. http://dx.doi.org/10.1037/0021-9010.86.4.629

Wang, S., \& Zhang, D. (2020). Perceived Teacher Feedback and Academic Performance: The Mediating Effect of Learning Engagement and Moderating Effect of Assessment Characteristics. Assessment \& Evaluation in Higher Education, 45(7), 973-987. https://doi.org/10.1080/02602938.2020.1718599

Xhomara, N., \& Bara, G. (2018). The Relationship Between Lecturer Feedback about Academic Performance and Academic Progress of Students. European Journal of Education, 1(2), 714. http://dx.doi.org/10.26417/ejed.v1i2.p7-14

Yearta, S. K., Maitlis, S., \& Briner, R. B. (1995). An Exploratory Study Goal Setting in Theory and Practice: A Motivational Technique that Works? Journal of Occupational and Organizational Psychology, 68, 237-252. https://doi.org/10.1111/j.20448325.1995.tbo0584.X

Yusuff, K. B. (2018). Does Personalized Goal Setting and Study Planning Improve Academic Performance and Perception of learning Experience in a Developing Setting? Journal of Taibiah University Medical Science, 13(3), 232-237. https://doi.org/10.1016/i.jtumed.2018.02.001 